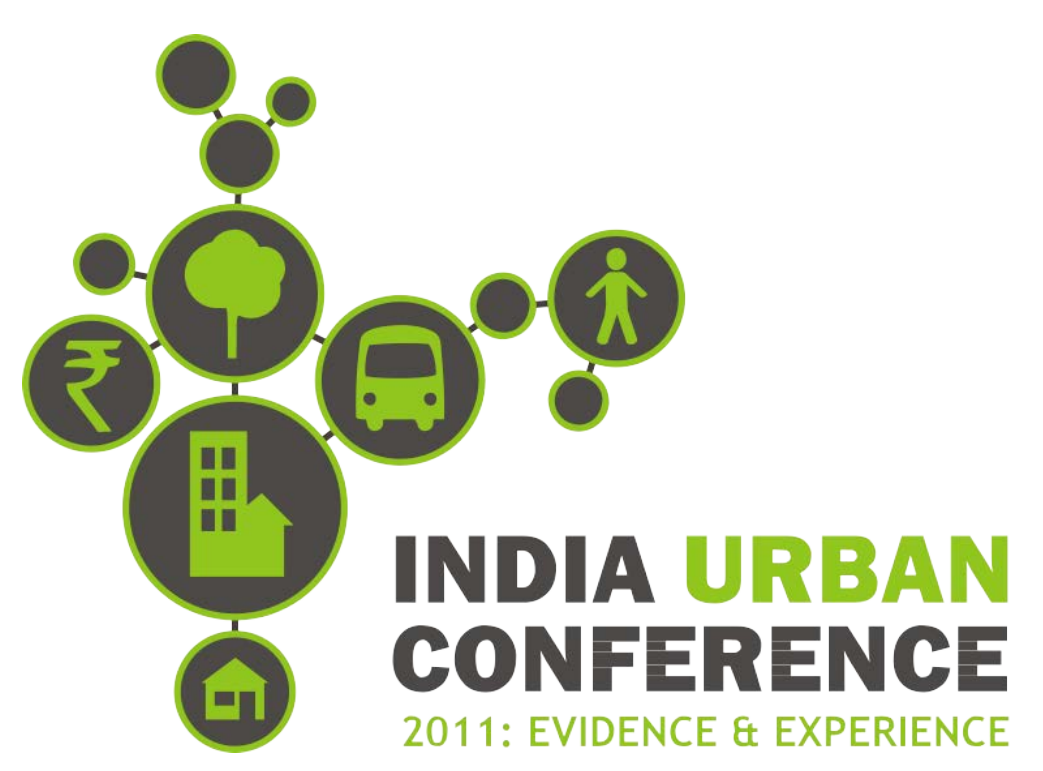

\title{
Housing Solutions: A Review of Models
}

A Background Paper for "Re-visiting Upgrading: Low-Income Housing and Infrastructure" India Urban Conference

Mysore, November 18th, 2011 



\section{Executive Summary}

This paper compares some of the main models of housing provision being debated in India at present. These models utilise a variety of actors and sources of funding to deliver housing to low-income residents.

For instance, slum upgrading programmes have been implemented in numerous formats. Under the publicprivate partnership (PPP) model of slum upgrading, developers are handed over slum land and given additional Floor Space Index (FSI) to rehabilitate slum dwellers and build market rate housing on the same plot. The idea is that market rate housing will cross-subsidise the cost of resettlement housing, which is then given for free to slum dwellers. However, this model poses a number of problems, most notably that given developer incentives, slum dwellers are often inadequately housed and end up being worse off post- resettlement.

A more successful model of slum upgrading is the Slum Network Partnership (SNP) model which has been implemented in Ahmedabad. SNP is unique in that it has managed to create partnerships between local government, NGOs, private

industry and the slum communities themselves to design, finance and implement slum upgrading projects.

However, while this programme has been successful, one of the biggest challenges has been retaining a private sector player in the equation. Without this, it is the slum dwellers and the municipal corporation that must share the bill for upgradation, which limits the extent to which the project can be scaled.

A third model of upgrading explored here is the community-managed eviction and resettlement model that was followed in rehabilitating families affected by the Mumbai's Railways improvement project. Here, like with the SNP project, slum dwellers themselves played an active role in the project. They were instrumental in choosing their relocation site, designing their new homes and orchestrating the move. Like with SNP, slum dwellers contributed financially towards the cost of their homes. This model has demonstrated the power of strong community leadership but also highlighted the need for local government to cooperate in preparing the relocation site for new residents.

Two international examples of slum upgrading are examined in this paper. The Baan Mankong upgrading project in Thailand is unique in that it channels infrastructure subsidies and money for soft loans, to slum communities themselves. Communities are responsible for managing their own budget through which they must finance infrastructure and shelter upgrades and secure land tenure for themselves. This programme is innovative in that it places the responsibility of identifying and acquiring land for slum upgrading projects on the slum communities themselves. This is a radical change in thinking from previous programmes - be it public housing programmes, slum upgrading or sites and services projects-where the responsibility for making land available rested squarely with the government. It is also innovative in that it takes a whole city approach to upgrading-linking slum improvement projects across the city rather than having them take place in silos.

The Orangi Pilot Project in Pakistan is another innovative model under which slum communities assume responsibility for designing, building and financing internal sanitation infrastructure in the areas by themselves. The local government then works closely with slum dwellers to provide the external infrastructure that connects their internal network to the main city pipelines. It was found that communities can self-finance, manage and build, provided they are given technical support and managerial guidance. Moreover, communities are able to undertake this exercise for almost a tenth of the amount that it would cost local authorities.

The paper then turns to a model for the market provision of low-income housing. This model, proposed by the Monitor Group, envisions that developers will build homes in the 3 to 11 lakh range for households earning Rs $8,000-11,000$ a month. These households currently live in poor quality rental housing and often lack access to proper or individual water and sanitation facilities and basic amenities such as gardens, proper street lighting, drainage, etc. They can afford to move out of this housing but are constrained by the lack of an affordable housing supply. On the developer side, Monitor demonstrates how builders can enter this market and make good returns. This model, unlike some of the others, is thus premised entirely on ownership housing and secure, transferable property rights. The biggest drawback to this model is that developers, as private and not government bodies, can do little to correct the fundamental distortions that make housing unaffordable in most cities. Thus, working within the parameters of a badly functioning land market, these projects must generally locate in peripheral areas in order to avoid exorbitant land costs. These areas might not only be locationally unsuitable to poorer citizens (due to high transport costs) but also often lack good social infrastructure facilities. At the same time, this model is unique in that it recommends turning the existing modus operandi in the construction sector on its head, focussing instead on the quick turnaround of projects, mass production and innovation in building techniques to provide a package of housing, infrastructure and amenities.

The last section of this paper explores the housing solution proposed by McKinsey. McKinsey's approach to the urban low-income housing problem emphasises the provision of shelter over owner-occupied housing. Towards this, proponents of this approach encourage the development of rental housing, dormitories and hostels as much as that of ownership units. In addition to encouraging a range of tenure options, they recommend flexibility in size and format of housing to cater to the varied urban demographic and also to ensure the longer term sustainability of the housing stock as income levels rise. McKinsey envisions the government as both a facilitator (through policy making) and direct contributor to LIG housing. A significant role for the private sector is also recommended. Demand and supply side mechanisms play an important part in McKinsey's model. On the demand side they suggest an increase in the interest subsidy on affordable housing loans from 5 to 7 percent. They also advocate the creation of a mortgage guarantee fund that will enable middle-income group (MIG) households to borrow more easily. On the supply side, other than the incentives to developers, they recommend streamlining the tax regime to reduce the tax burden.

While this model is no doubt a more integrated and holistic, long-term approach to the housing problem than some other interventions, it is similar to the Monitor approach in that it completely de-emphasises in-situ upgradation and ignores the informal housing assets. Both models also suffer from a lack of integration with the public planning process. 


\section{Introduction}

This paper looks briefly at some of the main categories of housing solutions being discussed in India today-slum upgrading, market provision of housing for lower income groups, and mixed models that recommend the development of a mix of rental and ownership housing by both the private and public sectors.

How we think about housing and its beneficiaries has implications for the housing solutions we choose. Slum upgrading, for instance, recognises the investments the poor (and sometimes the government) have made in informal housing and supplements, and legitimises their efforts rather than destroying them. Under the market provision of housing, designed to cater to segments of the low and middle income market, beneficiaries are viewed as willing consumers of housing who have been forced into informal housing because of the lack of options available to them. This is a marked change from past interventions that have seen slum dwellers as uniformly unable and unwilling to contribute towards better housing.

Under the mixed model of provision, a mix of tenure types, housing sizes, public and private housing is envisioned. This approach takes a long-term view of the housing problem and argues that a mix of options enables flexibility, affordability and non-obsolescence of the housing stock. In this model, the government is envisioned as both an active enabler and direct provider of housing, with the private sector also playing a critical role.

Other approaches are examined in the accompanying cross-comparison table. The National Alliance of People's Movements (NAPM), for example, takes a stand against PPPs, and argues in favour of property rights for the poor, at their current locations.

Compared to the other approaches discussed here, it completely shuns the involvement of private capital in the process of housing provision. Other interventions, like the housing loan scheme from the Self-Employed Women's Association (SEWA) Bank, concern themselves less with advocating a particular model of housing provision, and focus instead on enabling the choices the poor make for themselves, through micro-credit. The above-mentioned approaches, their implementation strategies, their underlying philosophies, their strengths and limitations, are examined here to form the basis of a constructive discussion on the way forward.

\section{A. Slum Redevelopment Schemes}

Slum redevelopment schemes (SRS) have been carried out under a number of different 'models' over the years. This section examines three of these: (i) the public- private partnership model (or 'Mumbai model', termed so for its famous proposed use in Dharavi), (ii) the slum network partnership model used in Ahmedabad, and the (iii) community-managed eviction and resettlement model that was followed in rehabilitating families affected by Mumbai's Railways improvement project. It also looks at two well-documented, innovative and successful slum upgrading projects-Baan Mankong in Thailand and the Orangi Pilot Project in Pakistan.

(i) Public- Private Partnership or 'Mumbai' Model

Under this model, which has been proposed for use in Dharavi, Golibar and elsewhere in the island city, land is handed over to a developer, who in turn receives additional Floor Space Index (FSI) to build both market rate housing for sale and rehabilitation housing for slum dwellers.

The rationale is that the sale of market rate units will cross-subsidise slum rehabilitation units on the same plot. Slum dwellers typically get these units with full ownership rights although it is conceivable that other tenure arrangements and resale rights might be negotiated.

The main actors in this process are the private developers who bid for redevelopment rights, the local or state government and/ or the relevant rehabilitation authority. Community participation has not been considered as part of this model. In some cases, developers are required to make a monetary contribution on behalf of each dwelling unit, which goes towards establishing the co-operative society for resettlement housing.

This model appears appealing for its simplicity and the fact that it imposes practically no burden on the government. However, not only has it shown limited uptake and poor potential for replicability, it is also fraught with problems, many of which impose severe externalities on the rest of the city. According to the NAPM, only about 100,000 units have been built under such schemes in the past 12 years, and 35 per cent of beneficiaries have moved back into slums because they cannot afford the cost of maintaining the resettlement units (Patel, 2011).

From a replicability perspective, profits and the ability to cross-subsidise appear to be linked to the attractiveness of the site location itself and to real-estate cycles. Moreover, the plot needs to be large enough (or FSI set high enough) to accommodate not only existing slum dwellers but a substantial numbers of high income group (HIG) families as well. While part of the financial viability problem could be offset by having resettled families make a financial contribution towards their new unit (as advocated by SPARC and other prominent NGOs/ activists in the field), housing is currently provided for free, often for political mileage. Thus, while some slums might be attractive prospects for redevelopment, this model does not offer a solution for the entire city.

There are also more troubling issues. The most attractive schemes are those where the slums are located on prime real estate. Given the developer's profit motive, what are the incentives to provide good quality homes to the residents? As has been observed in schemes implemented to date, housing provided is typically of poor quality and of the minimum size required. These schemes also often ignore the social fabric of slums and do not compensate for the loss of informal commercial space that is critical to urban poor livelihoods. There is a perverse incentive to maximise the amount of space that can be used for higher income units. Thus, it is often argued that slum redevelopment schemes undertaken with this model are little more than disguised land grabs on the part of greedy developers and politicians. Eligibility terms, determined by a cut-off date, have been shown to be such that a large majority of slum dwellers become ineligible for resettlement.

Cross-subsidisation essentially imposes the cost of providing resettlement units onto the market rate units. As Annez, Bertaud, Patel and Phatak (2010) argue, the formal housing market is already heavily taxed-McKinsey (2010) puts this tax at approximately 27 per cent over the cost of the house itself. Making housing more expensive not only skews housing prices in the city but also serves as a disincentive to HIGs to purchase such housing. Annez et al. (2010) argue that when HIGs choose 
to stay on in their existing units, due to unaffordable alternatives, this blocks housing units that could have otherwise been purchased by MIGs. By constraining dynamism and affordable supply in the formal housing market, and raising overall prices, such schemes run the risk of pushing even more families into informal housing.

Slum redevelopment schemes increase the resident density of the sites they are implemented on. This strains existing infrastructure with negative externalities for the surrounding areas. As Annez et al. argue, Merely trading higher FAR for apartments for slum dwellers without extracting charges for the infrastructure that is essential to supporting new developments will aggravate the already substantial shortfalls in urban infrastructure. FAR schemes should not be an excuse for continuing the unfortunate past practice of urban development on the cheap. J ust as the Development Authority business model has done, TDRs designed to focus only on provision of low cost housing without recognizing the need for additional infrastructure miss an opportunity to use the fiscal potential that these transactions offer' (2010, p. 30).

The issue of impact fees above raises the question - how can one regulate schemes such as this, with the right set of sticks and carrots, so that the immense potential for private sector financing is retained, while protecting the interests of the urban poor?

(ii) In-Situ Slum Upgrading-The Slum Network Partnership Model

The Slum Networking Project (SNP), an upgrading programme that has received accolades for its work in Ahmedabad, showcases the 'network partnership model'. SNP was unique in that it created a partnership between local government, NGOs, private industry and the slum communities themselves to design, finance and implement slum upgrading projects.

As part of the 2006- 2012 City Development Plan for Ahmedabad, it was noted that 32.4 per cent of the city's population still lived in slums (as cited in Marshall, 2010). A significant portion of these families was below the poverty line. Moreover, slums were treated as separate entities in the city without any linkages to the main city or its infrastructure.

The SNP decided that to improve the conditions of slum dwellers, it was crucial to enhance their linkages with citywide infrastructure and services. The main objectives of the programme were to improve the physical and nonphysical infrastructure facilities within selected slum areas, to facilitate the process of community development, and to develop a city-level organisation for slum networking and infrastructure improvement.

In its first phase, SNP was undertaken as a three-way partnership (40-30-30 funding split) between the Ahmedabad Municipal Corporation (AMC), a local private sector textile firm Arvind Mills (acting through their SHARDA Trust) and the slum community themselves. The NGOs, SAATH and SEWA's Mahila Housing Trust that had a long history of working in the community were also key partners in the project and provided microfinancing facilities in addition to other community mobilisation efforts. The approximate upgrading cost of Rs 3,000 per dwelling unit was shared by the parties as above, with slum dwellers allowed to take loans from SEWA and SAATH in order to make their contribution (Marshall, 2010).

To encourage slum dwellers to continue to invest in their homes, the AMC agreed to extend written assurance of a 10-year secure tenure to households participating in the programme.

After the initial pilot programme, Arvind Mills pulled out and the programme has been funded as an 80:20 AMCslum community split. Over time, the programme has largely become one that focusses on infrastructure provision

(e.g. individual taps, bathrooms, street lighting and paved roads) and public health.

Between 1996 and 2005, SNP upgraded 8,400 dwellings in 45 slum communities, serving an estimated 39,000 people (Marshall, 2010). The project has been widely regarded as a success and as a recognition of the attempts and investments of the poor to enter the formal housing market. However, critics argue that SNP has offered little choice in the package of services provided which meant residents could make inputs in project design.

AMC itself has complained about the slow pace at which the project has proceeded, the very low levels of participation by NGOs (which in turn affects the pace of upgrading), and the high share of funding shouldered by them, and the erosion of their efforts as slums continue to grow (Ahmadabad Municipal Corporation, 2008).

A number of interesting issues are raised by this project:

- How does one engage with and create incentives for private sector involvement in projects where there is no profit motive? Arvind Mills pulled out of the project citing organisational conflict and the large costs involved (Chauhan \& Lal, 1999).

- The issue of tenure is not always clear-cut, depending on the nature of land ownership in the city or state. According to Bijal Bhatt (personal communication, 14 J uly 2011), about 75 percent of Ahmedabad's slums are located on 'private' lands that were actually sold to slum dwellers many years ago. However, many of those private owners now deny that sale as a result of which there are a multiplicity of landowners and claims.

Box 1: Delinking tenure and basic services for slum electrification in Ahmedabad

The success of SNP stimulated a slum electrification project as a partnership between AMC, SAATH, SEWA and the private utility, the Ahmadabad Electric Company (AEC). This project actually has more extensive coverage than SNP, catering to 10 per cent of slum dwellers in the city versus the 1 per cent covered by SNP (Marshall, 2010). The project effectively delinks tenure and services as in providing the No Objection Certificates (NOCs) and permissions for road opening, it can be argued that the AMC has effectively ceded tenure to the households covered. However, as described by the Mahila Housing SEWA Trust, the AEC has made households sign an indemnity bond that they will not pursue any legal proceedings with AEC if they are evicted or relocated from their homes (as cited in Marshall, 2010).

- In the absence of private or other funding, how sustainable or scalable can such projects be? Post the withdrawal of Arvind Mills, the AMC noted in their 2006 City Development Plan (CDP) that despite the SNP including a cost sharing component, they were shouldering the majority of the financial cost (as cited in Marshall, 2010). This can have implications for the pace and 
scale at which upgrading can continue-already the AMC has found that the pace of upgrading has been slow (ibid.).

- Das and Takahashi (2009) note that such projects require considerable capacity on the part of NGOs. Moreover, many NGOs complained that the importance of their community organisation and training projects were not recognised and that they were not given adequate time or weightage for implementation. Over time, capacity building and the institutionalisation of frameworks to govern the interaction of different parties might reduce such roadblocks.

- Upgrading programmes also need to be pre-emptive and operate in conjunction with programmes to build new housing so that further proliferation of slums is avoided. It might be argued that upgrading runs the risk of encouraging further informal settlement. AMC notes that as growth within SNP-serviced slums continues, existing infrastructure is becoming inadequate (as cited in Marshall, 2010).

Some key lessons are as follows:

- Community participation and involvement are crucial. Not only is this instrumental in successful project design and implementation but it also helps ensure that the cost of maintenance is affordable to the community.

- Programmes should have synergy with other city and national level poverty reduction programmes for maximum effectiveness.

- Implementation should be at an appropriate scale to enable responsiveness. In this case, the most effective level of implementation has proved to be at the municipal level, together with the community and supporting intermediaries such as NGOs or multilateral agencies.

- The right to shelter is more important than focussing solely on granting property rights. According to Bhatt (personal communication, 14 J uly 2011), once the authorities provide a basic level of tenure security and a package of basic services people will invest in their own houses and thereby reduce the amount of public contribution required. Full property rights can be looked at at a later stage in the project, with the immediate focus being on guaranteeing basic security of tenure and the right to shelter. This is especially important in cases where the process of securing full property rights is difficult and may take years, if at all.

- It is important to work with an acceptance of a housing continuum. Similar to the tenure issue, Bhatt (personal communication, 14 J uly 2011) argues that project managers should not be fixated on providing a fully constructed house if that is not what is feasible at first. Housing can be upgraded incrementally as long as financing and tenure are available. Bhatt (ibid.) suggests that development control regulations (DCRs) be relaxed particularly for slum upgradation; insisting on certain road widths or setback areas that reduce the amount of space in a household or increase costs limits the effectiveness of these programmes.

(iii) Community-Managed Eviction and Resettlement

Between 2001 and 2002, the Society for the Promotion of Area Resource Centers (SPARC) oversaw a communitymanaged eviction and resettlement process whereby
60,000 low-income people residing by the railway tracks had an active relationship between government and NGOs. In total it constituted a participatory, decentralised, multi-stakeholder approach to eviction and resettlement that preserved the right to housing for slum dwellers and created a sustainable relocated community.

The state government's task force on rehabilitation recommended that each project-affected family be given a 225 square foot apartment at no cost. The main actors in this plan were the Mumbai Metropolitan Regional Development Authority (MMRDA), the state government, the Railways Slum Dwellers Federation (RSDF), and the Alliance - a three-way partnership between SPARC, the National Slum Dwellers Association and a women's savings collective, Mahila Milan. A joint sector company, Mumbai Railway Vikas Corporation was set up by the state government and the Indian Railways to implement the rail project, and a partnership of the state Public Works Department and the Mumbai Corporation of Greater Mumbai was set up for all non-rail projects.

For almost a decade prior to this project, the RSDFC had carried out mapping and data collection exercises about the settlements along the tracks. They had also helped set up women's savings groups and had encouraged the formation of cooperative housing societies. To prepare themselves for active engagement in a permanent housing solution, they had also got people to think actively about the kind of housing that they would like to aspire towards and what they could afford at the present; at a model housing exhibition slum dwellers were asked to build life size models of these homes (Patel et al., 2002). At the time the issue of eviction was discussed with RSDF, they expressed their willingness to move provided they were given secure tenure at an appropriate location.

Some permanent buildings were to be constructed whereas others were to be purchased within a Maharashtra Housing and Area Development Authority (MHADA) housing colony. However, it was not possible to have permanent accommodation ready for all those to be moved by the relocation date so some families were made to stay in transit accommodation. The potentially divisive issue of who would get transit accommodation was solved using community management. Priority was given to those who were old or sick, or based on residents' length of involvement in savings schemes, etc. This allowed little scope for interference by politicians or other external elements.

When unplanned demolitions were undertaken by the railways prior to the planned move date, the affected families were given transit accommodation of 120 square feet, with access to basic amenities. To avoid delays due to the World Bank's extensive tendering process, the Alliance offered to build transit accommodation at twothirds the cost estimated by the Bank and the MMRDA, with a contribution towards costs coming from slum dwellers' savings and loans.

For the most part, households were satisfied with the move. There were a number of issues, as described below, and a number of these are being addressed though ongoing engagement with the community.

- Adjustment to a new location: Since most of the resettled population is four railway stations away from where they previously lived, there are now extra costs in terms of time and railway fares for those who used to work close to their former homes. There are also fewer work opportunities in the new location, particularly for women who worked as maids in their old 
neighbourhoods and could walk to work. Small business that used to be set up on the street close to the slum have found lower demand in the new area. To address this, the savings scheme made Rs. 50 lakh available in loans for income generation schemes. Circulation was to be administered through Mahila Milan.

- Capacity of social infrastructure: Schools and other social infrastructure in the new area became inundated with the influx of new residents. To address this, buses have been organised to ferry children to their old schools. Residents also faced difficulty in accessing ration card shops or old community cooperative stores and getting regular garbage collection services from the municipality. Community groups and the Alliance are working on getting names on electoral rolls and addresses on ration cards changed. Committees, mainly of women, have been organised to deal with the municipality on issues such as water, sanitation and garbage collection.

A few key lessons from this project are as follows:

- Strong community participation is important, particularly the involvement of women: As seen with the SNP, the need for strong and representative community participation is key to successful design and implementation. Women's collectives played a critical role in this project, and in setting up the maintenance and cooperative societies needed to manage the housing, going forward.

- Flexibility in key institutions and individuals can circumvent roadblocks: For example, the World Bank and MMRDA had to adapt some of their standard procedures and guidelines. For example, as per the Bank's policy, normally the contract for the baseline socio-economic survey, drawing up of the resettlement action plan and implementation would have to be tendered and given to different contractors. However, in this case they decided to give it solely to the Alliance. The Bank also relaxed its procedures in giving more money to the Alliance to build transit accommodation than it is usually allowed to give an NGO. The MMRDA, on its part, was willing to cede the responsibility of determining eligibility and allocation to a community organisation although these two functions are usually only given to a government.

- A two-phase strategy can help expedite the process: Having people move before all the permanent accommodations were ready helped give the railways quick access to land. It also drew people into the process when they moved to their transit accommodation.

Box 2: Other examples of community-managed resettlement programmes

J an Kalyan Project

In 1989, to make way for the construction of a rail link, it was proposed to evict and resettle a group of slum dwellers in government-built walk-up apartments at a cost of Rs. 58,000 each. Since 150 of the affected families could not afford this, the community identified vacant land adjacent to the government's relocation site, which was then allocated to these families to build their own homes. These households were developed as 180 square feet apartments with a loft of an additional 100 square feet. These homes cost just Rs.16,000 at the time and were funded using housing loans.

Kanjur Marg Project

In 1999, the Alliance managed the resettlement of 900 families when the Indian Railways needed land cleared on an urgent basis. The families were involved in the selection of the resettlement site, which was located 12 kilometres away from their original homes. The families were also organised into 27 housing cooperatives

that would assume responsibility for managing the resettlement housing in the future.

\section{(iv) Upgrading models elsewhere}

Various models of upgrading have taken shape around the world. Some of the most innovative and successful models undertaken on a significant scale are the Baan Mankong project in Thailand and the Orangi pilot project in Pakistan.

\section{a. Baan Mankong, Thailand}

The Baan Mankong programme was launched in Thailand in J anuary 2003 to help address the housing needs of the poor urban slum populations. Under the programme, the government channels infrastructure subsidies and money for soft loans, to slum communities themselves. Communities are responsible for managing their own budget through which they must finance infrastructure and shelter upgrades and secure land tenure for themselves (Boonyabancha, 2009).

This programme is innovative in that it places the responsibility of identifying and acquiring land for slum upgrading projects on the slum communities themselves. This is a radical change in thinking from previous programmes-be it public housing programmes, slum upgrading or sites and services projects-where the responsibility for making land available rested squarely with the government. It is also innovative in that it takes a whole city approach to upgrading-linking slum improvement projects across the city rather than having them take place in silos. Boonyabancha (2009) argues that the programme responds to the existing reality in urban areas where the increasing commercialisation of land means that land gets allocated to the highest bidder, with allocation of land to the poor taking a backseat. It also counters the argument often put forth, that there is no urban land in central locations in particular, on which to house the poor.

The key players in this scheme are the Community Organizations Development Institute (CODI) (a public organisation housed under the Ministry of Social Development and Human Security) and the slum communities themselves. Other actors include municipal governments, local universities and NGOs and interested professionals.

In the initial part of the programme, all the actors work together to produce a survey of slum settlements in a city, select projects for upgradation, and prepare a city-wide plan that incorporates each of the individual projects.

Therefore, although the programme is decentralised, in its implementation slum communities work very closely with local authorities and in conjunction with other urban development programmes. Some cities have formed city development committees with mayors acting as the head or chairperson, while others have adopted a looser format. 
For a slum community to be eligible to participate, it must first set up a savings and credit group in which all residents must be members. This savings group will pool together community savings to supplement the external funds that will be received through the programme. Next, community cooperatives must be established to act as the collective legal entity in whose name the land will be acquired, and who will receive the subsidies, loans and other funds.

Slum communities, acting through their community groups are responsible for finding the land on which secure tenure can be obtained. This land could be all or a portion of the land they occupy already, or an alternative site, and could be public or private land. Negotiations then ensue to determine the type of tenure-for example, leasehold, freehold - that the slum communities will have, and the price at which this will be obtained.

CODI then loans the money for this transaction to the community at a subsidised interest rate. Loans are subject to a cap usually determined on a per household basis. CODI also loans money for shelter upgradation to community groups, who further lend the money to their members, at a slightly higher rate of interest. Using this method, more than 90 per cent of the communities in the programme have managed to get substantially more secure tenure than before (Boonyabancha, 2009).

Once tenure has been secured, infrastructure subsidies from national and local government help pay for the cost of internal and connecting infrastructure to the site. Households are responsible for upgrading their individual households using housing loans as described above. In some cases, communities chose to re-block their area while in other cases it is only homes that are upgraded.

\section{b. Orangi Pilot Project, Pakistan}

Orangi is a town close to Karachi in Pakistan whose model for slum upgrading has received widespread attention internationally. The Orangi Pilot Project (OPP) was launched in 1980 to overcome the constraints faced by government in upgrading katchi abadi or slum settlements. Under the model, slum communities assume responsibility for designing, building and financing internal sanitation infrastructure in the areas by themselves. The local government then works closely with OPP activists to provide the external infrastructure that connects their internal network to the main city pipelines. Over time, OPP activists have established themselves and now regularly negotiate with local provincial and federal government representatives or serve as advisors to city government officials for such upgrading projects (Hasan, 2006).

The project comprises four elements-sanitation, employment, health and education. In 1988, each part of the project became an autonomous institution. However, it is the low-cost sanitation project that has received the most attention.

The Orangi Pilot Project - Research and Training Institute (OPP-RTI) low-cost sanitation programme supports communities to develop their own internal sewerage development (this includes latrines in the house, underground sewers in lanes, neighbourhood collector sewers, etc.) linked to external development-trunk sewers and treatment plants. The sanitation system developed by the OPP-RTI uses and augments the community's existing informal sewerage that often uses the natural gradient of the land to empty into various natural drainage channels.
It was found that communities can finance, manage and build provided they are given technical support and managerial guidance. Moreover, communities are able to undertake this exercise for almost a tenth of the price that it would cost local authorities. For example, what costs them Rs. 90 million (USD 1.4 million) would have cost the government Rs. 630 million (US 10.5 million) (Hasan, 2006). In implementing the project, OPP-RTI does not collect money from residents who instead collect and manage funds within their communities.

Mapping is an essential part of this process in order to document the existing infrastructure. Previously, the lack of maps had made it difficult to plan infrastructure expansion into these areas as government-made maps used for electricity grids, land use, water and sanitation networks traditionally excluded these areas. OPP-RTIsupported NGOs have developed strong partnerships with local authorities and frequently act as advisers as more government agencies and departments begin to adopt this methodology.

This method recognises the existing investment households have made in creating drainage and sewage networks, although some of these, such as pipes that tap into city water mains, are illegal. Over the years, substantial portions of transfers from the national and provincial governments for development of infrastructure have been spent on these areas. However, since none of it has been documented it is usually destroyed along with residents' investments via the traditional upgrading route (Hasan, 2006).

Over time, planning agencies have realised the importance of supporting rather than ignoring the work done by this project. Active community involvement has shown the involvement of residents in the process of upgrading their settlements. The OPP-RTI has spread its mapping activities elsewhere in Pakistan and in Karachi, and has plans to digitise these maps. Through its programme it has provided learning to Community-Based Organisations (CBOs) and NGOs and started a Youth Training Programme in 1994 to involve youth in surveying and mapping. OPP-RTI's research has also developed new construction standards techniques and tools that are affordable for residents.

The project has proved to be highly successful. Public health has improved greatly in the areas covered. The model has also been scaled up to many towns other than Orangi. There is now an established community development network that links all partner organisations so that they can meet every quarter at a different replication project and discuss findings and issues. In two replication projects, water supply has been developed on an internal- external basis whereas in three other projects, the Orangi participants have become consultants to the government on water supply, sanitation and road paving projects.

\section{B. Market Provision of Housing}

\section{(i) Monitor model}

Monitor estimates that there is a market of approximately 21 million unserved urban households who can afford housing in the Rs. 3 lakh to Rs. 10 lakh band on their monthly household income of Rs. 8,00011,000. In terms of income brackets, Monitor estimates that this group constitutes the 30 percent that falls below the top 15 percent who can afford homes at current prices. Monitor's model is thus premised entirely on ownership housing and secure, transferable property rights. 
The target households are ones that currently live in poor quality housing and often lack access to proper or individual water and sanitation facilities and basic amenities such as gardens, proper street lighting, drainage, etc. The housing is occupied on rental basis, with renters often subject to harassment and frequent rent increases by landlords. While these households want to and could afford to buy their own homes of around 200-400 square feet in suburban locations, there has been no such supply of homes available to them ('Building Houses', 2010). Moreover, there have been few financing options that could cater to their (often) informal sources of income.

Monitor studies have shown significant developer interest in this market, both in major metros-Mumbai, Bangalore and Ahmedabad - and increasingly in smaller towns and cities-Meerut, Uttar Pradesh and Bawal, Haryana for example. In the fiscal year 2010-2011, they estimate that there were between 25,000 and 50,000 houses on sale in the market. Developer returns have proven to be as high as 40-50 per cent with gross margins of approximately 20- 30 per cent. In almost all locations, demand for these homes has outstripped supply ('Building Houses', 2010).

Thus the private sector appears to be the main player in the LIG housing market as envisioned by Monitor. As critically, however, there is a role for financing institutions. Beyond the traditional institutions, these include NGOs, housing or savings co-operatives but predominantly

micro-finance institutions (MFIs). Traditional players have generally been hesitant to extend finance to this demographic because of the lack of income documentation, credit information, low loan ticket size, difficult with traceability in case of default and the perceived high risk. However, MFIs have a crucial role to play in this market, and have demonstrated a willingness to take on such customers. Monitor credits Gruh and Dewan Housing Finance Limited (DHFL) with pioneering lending to the low-income informal sector customer. Some developers such as J anaagraha have dedicated MFIs (J anaadhan) to provide finance. Monitor estimates that MFIs will be profitable and can charge market interest rates of around 14 per cent on average. Large returns in turn will continue to attract players into this market.

The one large difference between the affordable housing model and the way in which housing has traditionally been developed to date is the issue of land. Previously, developers have treated land as an asset, held for price appreciation over time. In the current model, land as an input must be utilised as soon as possible to deliver housing as soon as possible. To be profitable, developers should aim to mass-produce homes on a large scale. Developers are also being innovative by experimenting with new time-reducing construction technologies, using new layouts that make small spaces more comfortable and introducing sustainability elements into their project design.

There are a number of issues with this model. For one, it has limited scope as it targets low-income households but excludes the issue of shelter for the poorest. Partly because of this, it does not pay attention to existing

'illegal' housing stock and assets. Another problem stems from the fact that developers, as private and not government bodies, can do little to correct the fundamental distortions that make housing unaffordable in most cities. Thus, working within the parameters of a badly functioning land market, these projects must generally locate in peripheral areas in order to avoid exorbitant land costs. These areas might not only be

Work in progress: Do not quote without author permission. locationally unsuitable to poorer citizens (due to high transport costs) but often lack good infrastructure facilities. In the absence of quick and affordable public transportation links, many households might be reluctant to relocate despite better living conditions. While it is the developer's responsibility to negotiate infrastructure provision with local municipalities or state agencies, interviews with developers have revealed that typically the cost of infrastructure provision falls on them, thus making it difficult for them to meet their affordability targets (personal communication, J une-J uly 2011). Lastly, since developers determine where they can find land and infrastructure with little input or regulation by local authorities, such projects often lack integration with any long-term public planning process. Thus an important question to ask is to what extent the government might enter as a critical facilitator in this model.

There is large and growing investment in this sector, yet it remains to be seen to what extent this will take the pressure off the government to provide housing. Although demand for these projects has been huge, and many properties have seen appreciation in value, it is not always LIG households that buy these properties; many are being bought by HIGs as speculative investments.

\section{Mixed Tenure, Shelter-Driven Approach}

\section{(i) McKinsey model}

McKinsey's approach to the urban low-income housing problem emphasises the provision of shelter over owneroccupied housing. Towards this, they encourage the development of rental housing, dormitories and hostels as much as that of ownership units, as they view the former as most suitable to addressing the needs of LIGs. In addition to encouraging a range of tenure options they recommend flexibility in the size and format of housing to cater to the varied urban demographic and also to ensure longer term sustainability of the housing stock as income levels rise. McKinsey's definition of affordability is similar to, if broader than, the government definition at 20-40 per cent of monthly household income ('India's Urban Awakening', 2010).

McKinsey envisions the government as both a facilitator (through policymaking) and direct contributor to LIG housing. As a contributor, they recommend that the government aim to provide 500,000 units annually on government or unviable slum land. In addition, the government should acquire land at the city periphery to build more affordable units but this land should be along transportation corridors. In its role as facilitator, the government should provide incentives to developers (as described in greater detail below) and use mandates (attached to planning permits for new development) to add to LIG housing stock. Local governments must also actively reserve and allocate land for building LIG units ('India's Urban Awakening', 2010).

A significant role for the private sector is also envisioned to increase investment in affordable housing while reducing pressure on the public exchequer. However, McKinsey estimates that even with mandates and incentives, the private sector can only address $\sim 40$ per cent of the gap. Amongst the incentives recommended are the use of additional FAR (up to a maximum of 1), a capital grant to developers for infrastructure, and allowing the use of up to 5 per cent of land for commercial spaces. For redevelopment of slums, they recommend a higher 
additional FAR of about 1.5 ('India's Urban Awakening', 2010).

Some institution building and restructuring is recommended. In particular, they recommend corporatised affordable housing agencies at the metropolitan/regional level. Where cities and towns do not fall under a metropolitan development authority, State Housing Boards should assist local and municipal governments. Other active institutions/ players could be:

- Slum dweller cooperatives, which can bid for redevelopment projects either by themselves or with a private developer.

- Rental management companies, which can operate and manage the rental stock.

- Private sector companies, which receive incentives to build housing for their blue-collar employees.

In terms of delivery methods, both demand and supply side mechanisms are recommended. On the demand side they suggest an increase in the interest subsidy on affordable housing loans from 5 per cent to 7 per cent. However, it is not clear how this will benefit those who cannot access formal credit markets. They also advocate the creation of

a mortgage guarantee fund that will enable middle-income households to borrow more easily.

On the supply side, other than the incentives to developers they recommend streamlining the tax regime to reduce the tax burden (currently at around 27 per cent of the final cost) on LIG households and creating the enabling infrastructure to augment the housing stock ('India's Urban Awakening', 2010).

This model is a more holistic approach to the housing solution than other models and takes a long-term perspective of the housing stock. However, similar to the Monitor approach, it de-emphasises in-situ upgradation and ignores the solution offered by the existing slum housing stock. In ignoring the provision of infrastructure in conjunction with housing, this model does not take an integrated city-wide approach to the housing problem, nor does it attempt to integrate with long-term public planning. With its over-emphasis on the provision of shelter in the most efficient manner possible (usually on a rental basis) this model also takes a narrower view of the attributes of housing, neglecting the fact that for many low-income households, their homes are also their places of work.

\section{Bibliography}

Ahmedabad Municipal Corporation. (2008). Slum Networking Project (Pro-active disclosure as per RTI Act 2008). Retrieved from

http:// www.egovamc.com/right_info/right_info.asp

Annez, P., Bertaud, A., Patel, B., \& Phatak, V. (2010). Working with the market: A new approach to reducing urban slums in India. Retrieved from http:// papers.ssrn.com/ sol3/ papers.cfm? abstract_id=1709847

Boonyabancha, S. (2009). Baan Mankong: Going to scale with 'slum' and squatter upgrading in Thailand. Environment and Urbanization, 17(1), 21- 46.

Chauhan, U., \& Lal, N. (1999). Public-Private Partnerships for urban poor in Ahmedabad: A slum project. Economic and Political Weekly, 34(10/11), 636- 642.

Das, A.K., \& Takahashi, L.M. (2009). Evolving institutional arrangements, scaling up, and sustainability: Emerging issues in participatory slum upgrading in Ahmedabad, India. J ournal of Planning Education and Research, 29(2), 213- 232.

Deb, A., Karamchandani, A., \& Singh, R. (2010). Building houses, financing homes. Retrieved from http:// www.mim.monitor.com/ downloads/ whitepaperBuildingHousesFinancingHomes-final-screen.pdf

Hasan, A. (2006). Orangi Pilot Project: The expansion of work beyond Orangi and the mapping of informal settlements and infrastructure. Environment and Urbanization, 18(2), 451- 480.

Marshall, S. (2010). Of squatters and schemes: Considering city-level strategies for housing the poor in India. Retrieved from DSpace@MIT.

McKinsey Global Institute. (2010). India's urban awakening: Building inclusive cities, sustaining economic growth. Retrieved from

http:// www.mckinsey.com/ mgi/publications/india urbanization/index.asp

Patel, N. (2011, March 11). Battle over Mumbai's slums. The Guardian. Retrieved from http:// www.guardian.co.uk

Patel, S., d'Cruz, C., \& Burra, S. (2002). Beyond evictions in a global city: People-managed resettlement in Mumbai. Environment and Urbanization, 14(1), 159- 172. 
INDIAN INSTITUTE FOR HUMAN SETTLEMENTS

IIHS aims to establish India's first privately funded and managed National Innovation University focussed on the challenges and opportunities of urbanisation in all itsaspects.

The University is intended to be a globally rankedinstitution.

The IIHS University will host an integrated programme of quality campus based education and research, practical trainingfor working professionals, distance and blended learning, anda whole array of consultancy services. The University will have a strong interdisciplinary orientation, incorporating both theory and praxis.

The Academic Programme will consist of globallybenchmarked Bachelors, Masters and Doctoral Degrees in Urban Practicebased on a wide set of disciplines and practice areas central toIndia's urban transformation. The Masters and Undergraduate programmes of the University will provide a deep understanding of a wide range of topics including the economic drivers of urbanisation, urban planning, the physical infrastructure, transportation systems, the social infrastructure and social justice, land and housing, public safety and disastermanagement, the environment and sustainability, and law and urban governance.

The applied research programme will help create a newgeneration of interdisciplinary researchers and a corpus of relevant India-centric knowledge.

IIHS's deep commitment to the process of social transformation in India by providing educational opportunities to deserving learners irrespective of economic and social status, gender, age or disability. 
